\title{
Multipotent cell lineages in early mouse development depend on SOX2 function
}

\author{
Ariel A. Avilion, Silvia K. Nicolis, ${ }^{1}$ Larysa H. Pevny, ${ }^{2}$ Lidia Perez, ${ }^{3}$ Nigel Vivian, \\ and Robin Lovell-Badge ${ }^{4}$
}

Division of Developmental Genetics, MRC National Institute for Medical Research, The Ridgeway, Mill Hill, London NW7 1AA, UK

\begin{abstract}
Each cell lineage specified in the preimplantation mammalian embryo depends on intrinsic factors for its development, but there is also mutual interdependence between them. OCT4 is required for the ICM/epiblast lineage, and at transient high levels for extraembryonic endoderm, but also indirectly through its role in regulating $F g f 4$ expression, for the establishment and proliferation of extraembryonic ectoderm from polar trophectoderm. The transcription factor SOX2 has also been implicated in the regulation of Fgf4 expression. We have used gene targeting to inactivate Sox 2 , examining the phenotypic consequences in mutant embryos and in chimeras in which the epiblast is rescued with wild-type ES cells. We find a cell-autonomous requirement for the gene in both epiblast and extraembryonic ectoderm, the multipotent precursors of all embryonic and trophoblast cell types, respectively. However, an earlier role within the ICM may be masked by the persistence of maternal protein, whereas the lack of SOX2 only becomes critical in the chorion after 7.5 days postcoitum. Our data suggest that maternal components could be involved in establishing early cell fate decisions and that a combinatorial code, requiring SOX2 and OCT4, specifies the first three lineages present at implantation.
\end{abstract}

[Keywords: Epiblast; extraembryonic; cell fate; pluripotent; stem cells; Sox genes]

Supplementary material is available at http://www.genesdev.org.

Received April 11, 2002; revised version accepted October 29, 2002.

Early embryonic development in mammals is characterized by a series of cell fate decisions that restrict developmental potential in an asymmetric fashion. There is, however, no evidence that this is caused by differential allocation of maternal cytoplasmic determinants as in many other animals. Although the fertilized egg may have a polarity that can predict the definitive axes of the later postimplantation embryo, this at best confers a bias to what is a very regulative system. Cell position seems more important. Thus, the first restriction of developmental potential to the trophectoderm lineage occurs in blastomeres located on the outside of the morula, whereas inside cells become inner cell mass (ICM). Subsequently, the ICM is specified into two lineages, embryonic ectoderm (epiblast), which gives rise to all cell types of the embryo as well as to extraembryonic meso-

Present addresses: ${ }^{1}$ Department of Biotechnology and Biosciences, University of Milano-Bicocca, Piazza della Scienza 2, 20126 Milano, Italy; ${ }^{2}$ Department of Genetics, School of Medicine, University of North Carolina at Chapel Hill, Chapel Hill, NC 27599, USA; ${ }^{3}$ EMBL, Meyerhofstrasse 1, D-69117 Heidelberg, Germany.

${ }^{4}$ Corresponding author.

E-MAIL rlovell@nimr.mrc.ac.uk; FAX 44-020-8906-4477.

Article and publication are at http://www.genesdev.org/cgi/doi/10.1101/ gad.224503. derm, and extraembryonic (primitive) endoderm, which is found on the surface of the ICM adjacent to the blastocoel cavity and contributes to the yolk sac ( $\mathrm{Lu}$ et al. 2001).

There is a dependence on each of these three early distinct lineages for the survival, patterning, and differentiation of each of the others during subsequent development postimplantation. The polar trophectoderm receives signals from the underlying ICM, triggering its proliferation and differentiation into extraembryonic ectoderm (ExE). This continues to proliferate and gives rise to the various trophoblast cell types of the placenta and to structures such as the chorion. Conversely, the mural trophectoderm, which is not in contact with the ICM, ceases to divide and terminally differentiates into primary trophoblast giant cells (Rossant and Cross 2001). The primitive endoderm also forms two distinct cell types around implantation: visceral endoderm (VE), which covers the epiblast and ExE, and parietal endoderm (PE), which lies adjacent to the differentiated trophoblast.

After implantation, rapid growth of the epiblast and ExE leads to the formation of the egg cylinder, with the dorsal-ventral axis of the future embryo already apparent. Although cells of the epiblast remain uncommitted 
until around the time of gastrulation, their patterning and differentiation are also specified by cell position (Tam and Behringer 1997). This is partly dependent on their location within the epiblast with respect to the primitive streak, but also with respect to extraembryonic tissues. For example, mutations in nodal and Smad2 have shown the importance of VE in patterning the epiblast; the anterior visceral endoderm playing a critical role in repressing posterior and inducing anterior properties and conferring neural fate to the underlying epiblast. Similarly, ExE is important for patterning the embryo as well as for its survival (Lu et al. 2001).

Because subsequent development depends so much on the interactions between the three lineages present within the peri-implantation embryo, it is crucial to understand the molecular mechanisms underlying their establishment. Fibroblast growth factor (FGF) signaling conducted through FGF4 and the fibroblast growth factor receptor 2 (FGFR2) is known to be essential (Rappolee 1999). Both are expressed in the blastocyst, with Fgf4 confined to the ICM and Fgfr2 to the trophectoderm (Rappolee et al. 1994; Haffner-Krausz et al. 1999). After implantation, Fgf4 is expressed throughout the epiblast (Niswander and Martin 1992), while Fgfr2 is restricted to the adjacent ExE (Orr-Urtreger et al. 1991). This differential expression pattern is consistent with the notion that FGF4 acts as a paracrine signal for trophectoderm proliferation or differentiation (Rossant and Cross 2001). The phenotypes of the Fgf4 and Fgfr2 null mutants are virtually identical: mutant embryos do not survive beyond implantation, and null blastocysts, which appear normal, fail to outgrow in culture (Feldman et al. 1995; Arman et al. 1998). The ICM degenerates, and, although giant trophoblast cells form, there is no discernible extraembryonic endoderm (ExEn). This suggests that FGF4 is also essential for the latter, which was verified with Fgf4 null embryonic stem (ES) cells (Wilder et al. 1997).

Apart from signaling molecules, transcription factors must act within each cell type to give them their characteristic properties; for example, to maintain or protect the pluripotent state of the ICM and to provide the paracrine signals to adjacent cell lineages for their survival. Two ideal candidates for this are the transcription factors OCT4 (encoded by the Pou5f1 locus, but referred to here as Oct4) and SOX2, which have been shown to cooperate in the transcriptional activation of $\mathrm{Fgf4}$ in F9 embryonal carcinoma cells (Ambrosetti et al. 2000).

OCT4, a POU domain protein, is expressed in the ICM, epiblast, and later in germ cells (Pesce and Schöler 2000). It is essential for establishing and maintaining pluripotency of the ICM, which in its absence differentiates into trophectoderm. Oct4 null embryos die around the time of implantation and fail to outgrow in culture. Interestingly, addition of FGF4 to Oct4 null blastocyst outgrowths or ES cells, which do not express Fgf4, fails to restore ICM pluripotency but rather promotes proliferation of trophectoderm. This is consistent with the involvement of OCT4 in Fgf4 regulation and in having additional functions that maintain pluripotency (Nichols et al. 1998; Niwa et al. 2000).
Sox2 is a member of the Sox (SRY-related HMG box) gene family that encode transcription factors with a single HMG DNA-binding domain. SOX2 belongs to the SOX B1 subgroup, which also includes SOX1 and SOX3, based on homology within and outside the HMG box (Kamachi et al. 2000). Several lines of evidence indicate that SOX2 may act to maintain or preserve developmental potential. For example, Sox2 expression is associated with uncommitted dividing stem and precursor cells of the developing central nervous system (CNS) and indeed can be used to isolate such cells (Li et al. 1998; Zappone et al. 2000). We show here that Sox2 also marks the pluripotent lineage of the early mouse embryo, so that like Oct4 it is expressed in the ICM, epiblast, and germ cells. Unlike Oct4, however, Sox2 is also expressed by the multipotential cells of the ExE. In both lineages its down-regulation correlates with a commitment to differentiate, such that it is no longer expressed in cell types with restricted developmental potential.

In light of the coexpression of all three factors in the early embryo, and the similar phenotypes of Oct4 and Fgf4 mutants, the same molecular hierarchy may exist in vivo. To elucidate the role of SOX2 in these early cell fate decisions, we have used gene targeting in ES cells to generate mice harboring a disrupted Sox2 gene.

\section{Results}

Sox2 expression in multipotent embryonic and extraembryonic lineages

Sox2 RNA is first detected in some cells at morula stages [2.5 days postcoitum (dpc); data not shown], and in blastocysts $(3.5 \mathrm{dpc})$ it is seen specifically within the ICM (Fig. 1A). Expression persists throughout the epiblast (Fig. 1B), but by mid-late-streak stages (7.0-7.5 dpc), it becomes restricted to presumptive neuroectoderm in the anterior, while it is excluded from the posterior, including cells ingressing through the primitive streak (Fig. 1C). A second site of expression initiates in the ectoplacental cone, and this is maintained in ExE at $6.5 \mathrm{dpc}$ (Fig. 1B) and later in the ExE portion of the chorion (Fig. 1C-E; Wood and Episkopou 1999). By $9.5 \mathrm{dpc}$, Sox2 RNA is seen throughout the brain, neural tube, sensory placodes, branchial arches, and gut endoderm (Fig. 1F). It is also present in both male and female germ cells (data not shown). Immunocytochemistry on adult ovary revealed high levels of SOX2 protein in growing and mature oocytes, primarily localized to the cytoplasm, and in some surrounding stromal cells (Fig. 1G,I).

\section{Targeted disruption of Sox2}

We generated a loss-of-function mutation in ES cells by replacing the Sox2 ORF with $\beta g e o$ (Friedrich and Soriano 1991) using homologous recombination (Fig. 2A). Although Sox2 is expressed in ES cells, the vector alone was not, therefore $\beta g e o$ will be driven by Sox2 regulatory sequences only upon integration via homologous recom- 

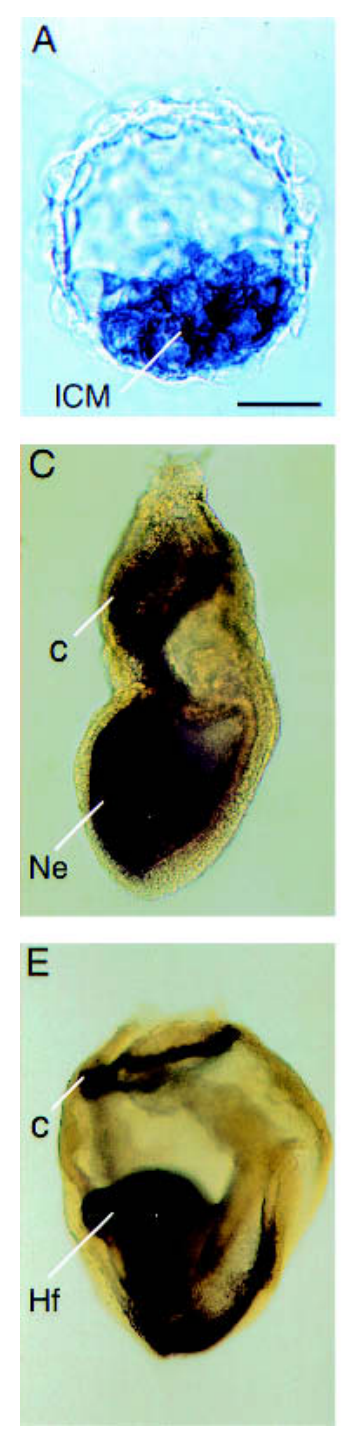
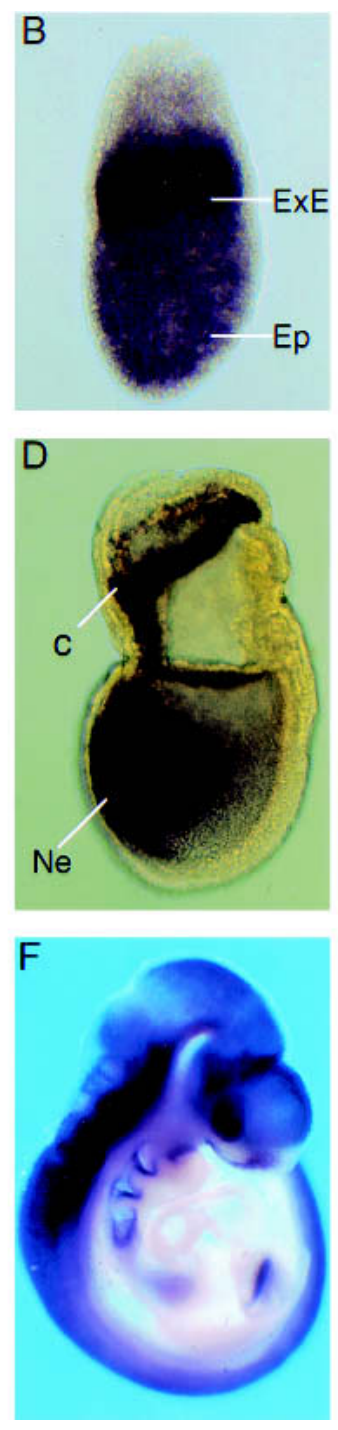

SOX2
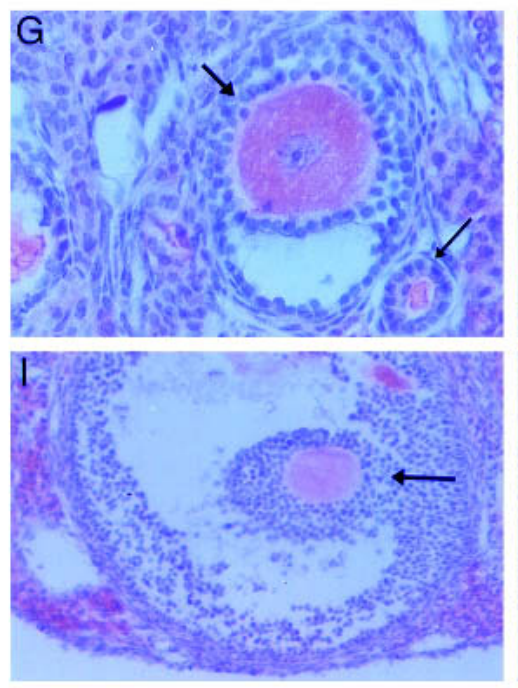

PI


Figure 1. Expression of Sox2 RNA in mouse embryos and SOX2 protein in oocytes. $(A-F)$ Whole-mount in situ hybridization in wild-type embryos. Sox2 RNA is seen in the ICM of the blastocyst $(A)$, throughout the epiblast (Ep) and extraembryonic ectoderm (ExE) of a 6.5-dpc embryo $(B)$, and in the chorion (c) and anterior region of the presumptive neuroectoderm $(\mathrm{Ne})$ of a $7.5-\mathrm{dpc}(C)$ and 7.5-8.0-dpc $(D)$ embryo. (E) At $8.5 \mathrm{dpc}$, Sox2 expression persists in the chorion, headfolds (Hf), and neural tube. (F) By $9.5 \mathrm{dpc}$, it is seen throughout the nervous system, sensory placodes, branchial arches, and gut. Anterior is to the left in panels $B-E$. $(G-J)$ SOX2 antibody staining in wild-type adult ovary. Sections were incubated with SOX2 antiserum $(G, I)$ or preimmune serum $(\mathrm{PI} ; H, J)$. Staining is observed in the cytoplasm of oocytes in a developing primary follicle $(G$, thin arrow), an early antral follicle $(G$, thick arrow), and a mature antral follicle (I, arrow). Bars: $A, 25 \mu \mathrm{m} ; B-D, 60 \mu \mathrm{m} ; E, 120 \mu \mathrm{m} ; F, 435 \mu \mathrm{m}$; $G, H, 20 \mu \mathrm{m} ; I, J, 53 \mu \mathrm{m}$.

bination. After selection with G418, 40 resistant colonies were analyzed by Southern blotting, and 7 were correctly targeted (Fig. 2B). After injection into C57BL/6J blastocysts, two clones generated chimeric males that transmitted the mutated allele through the germ line. Chimeras were crossed with MF1 and 129/SvEv mice to establish the mutation on both outbred and inbred genetic backgrounds, respectively.

Sox $2^{\text {Bgeo }}$ heterozygous mice appeared normal; however, there was a noticeable reduction in male fertility, the extent of which correlated with genetic background, being most severe on a $129 /$ SvEv background and variable when outbred. We also found similar effects on $1 a c Z$ expression, wherein only a minority of heterozygotes gave embryos showing lacZ activity. Even in these, the expression pattern was only partial at early stages (Fig. 2D-F). However, from $7.5 \mathrm{dpc}$, beginning with distally located presumptive neuroepithelial cells, it came to precisely match that of endogenous Sox2 (Fig. 2G-I), with the exception of the ExE. The most likely explanation for the incomplete expression pattern is the loss of impor- tant regulatory elements within the $2.7-\mathrm{kb}$ fragment 3 ' to the Sox2 ORF that are deleted after homologous recombination. This is consistent with recent data showing that an enhancer contained within the missing fragment activates expression of a luciferase reporter gene in ES cells (Tomioka et al. 2002).

\section{Peri-implantation lethality of Sox $2^{\text {Bgeo }}$ homozygous embryos}

Sox $2^{\beta g e o}$ heterozygotes were intercrossed, and their progeny were analyzed by Southern blotting or PCR genotyping. No newborn homozygous mutants were seen (Fig. 2C; Table 1). We looked at when the mutant embryos were dying, and found that although normal at blastocyst stages, they failed to survive shortly after implantation (Tables 1, 2; Fig. 4A,E, below). Results obtained with the two independent targeted clones are identical, and genetic background effects have not been observed for the homozygous phenotype.

Histological sections were prepared from whole de- 
A

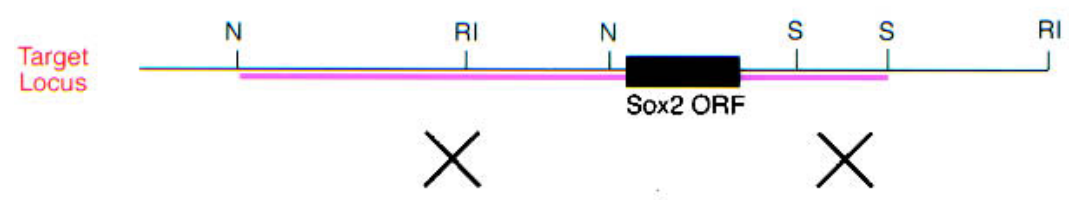

Replacement

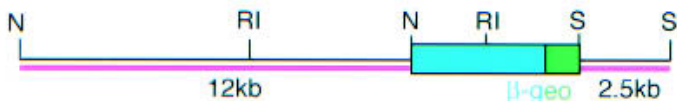

Vector

$12 \mathrm{~kb}$

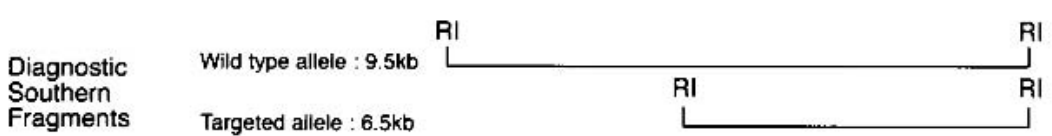

B

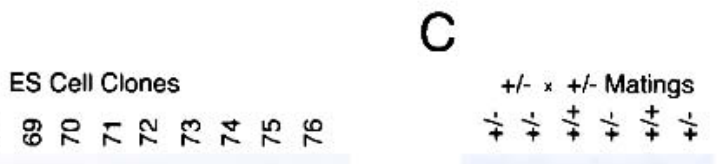
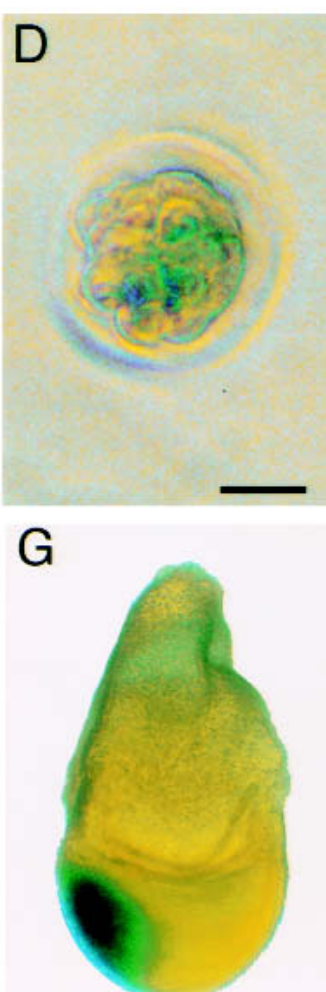
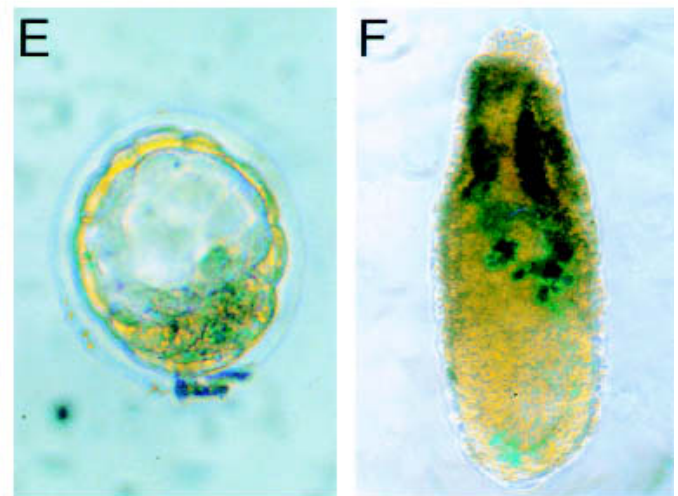

$\mathrm{H}$

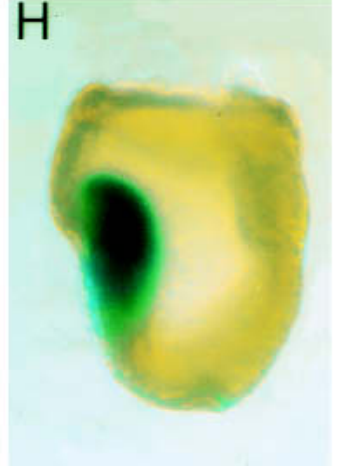

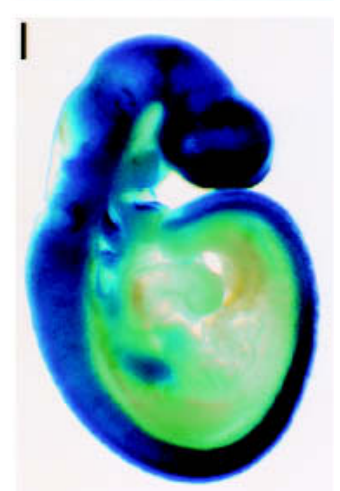

Figure 2. Targeted disruption of Sox2. (A) Schematic diagram showing the Sox2 locus, $\beta$-geo targeting vector, and predicted fragment sizes of wild-type and disrupted clones. The restriction sites are EcoRI (RI), SalI (S), and $\operatorname{NotI}(\mathrm{N})$. The thick solid bar in red shows the vector homology regions. (B,C) Analysis of DNA from ES cell clones and offspring from Sox $2^{\beta g e o}$ heterozygous matings. DNA was digested with EcoRI, and a 3' probe outside of the homology region was used on Southern blots (see $\left.A\right)$. TA, targeted allele. $(D-I)$ LacZ activity in Sox $2^{\beta g e o}$ heterozygous embryos. LacZ staining in a morula $(2.5 \mathrm{dpc} ; D)$, blastocyst $(3.5 \mathrm{dpc} ; E), 6.5$-dpc embryo $(F), 7.5$-dpc embryo $(G), 8.5$-dpc embryo $(H)$, and 9.5-dpc embryo $(I)$. Bars: $D, E, 25 \mu \mathrm{m} ; F-H, 65 \mu \mathrm{m} ; I, 370 \mu \mathrm{m}$. 
Table 1. Analysis of Sox $2^{\text {Bgeo }}$ heterozygous intercross progeny

\begin{tabular}{|c|c|c|c|c|c|}
\hline \multirow[b]{2}{*}{ Stage } & \multicolumn{2}{|c|}{ Phenotype } & \multicolumn{3}{|c|}{ Genotype } \\
\hline & Normal & Abnormal & $+/+$ & $+/-$ & $-1-$ \\
\hline 4 wk pp & 135 & 0 & $53(39 \%)$ & $82(61 \%)$ & $0(0 \%)$ \\
\hline $9.5-11.5 \mathrm{dpc}$ & 44 & $15^{\mathrm{a}}$ & $12(27 \%)$ & $32(73 \%)$ & $0(0 \%)$ \\
\hline $5.5-7.5 \mathrm{dpc}$ & $34^{\mathrm{b}}$ & $12^{\mathrm{b}}$ & - & - & - \\
\hline $3.5 \mathrm{dpc}$ & 35 & $2^{\mathrm{c}}$ & $11(30 \%)$ & $17(46 \%)$ & $9(24 \%)$ \\
\hline
\end{tabular}

${ }^{\mathrm{a}}$ Resorptions not genotyped.

${ }^{\mathrm{b} S a m p l e s}$ not genotyped.

${ }^{\mathrm{c}}$ One embryo was Sox $2^{+-}$, and the other Sox $2^{-/-}$.

cidual swellings at $\sim 6.0 \mathrm{dpc}$ from Sox $2^{\text {Bgeo }}$ heterozygous intercrosses. Abnormal implants had no egg cylinder structure and lacked epithelial cells typical of epiblast (Fig. 3). However, many trophoblast giant cells could be identified, as well as cells with characteristics of $\mathrm{PE}$; the latter often surrounded by a thick lamina secretion similar in appearance to Reichert's membrane.

RNA in situ hybridization was used to further characterize the cell types present in the abnormal decidua. Oct4 (Pesce and Schöler 2000) gave a strong signal in the epiblast on sections from wild-type or heterozygous embryos (Fig. 3E), but was completely absent in the abnormal decidua (Fig. 3F). H19 gives the reciprocal pattern of expression to Oct4, being diagnostic for all extraembryonic cell types in the early postimplantation embryo (Fig. 3C; Poirier et al. 1991). It was expressed throughout the area corresponding to the implantation site in the presumed homozygotes (Fig. 3D), clearly showing that extraembryonic cell types were present, with many positive cells invading the uterine stroma (typical of trophoblast giant cells). However, no structure comparable to the ectoplacental cone or to the extraembryonic part of the egg cylinder was seen. The abnormal decidua contain cells that express Evx1, a marker of VE (Dush and Martin 1992), but again in a disorganized pattern (Fig. 3H). These

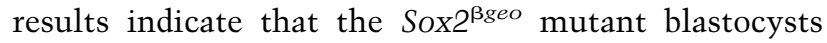
contain a relatively normal ICM, able to give rise to its earliest derivatives, but they fail to maintain an epiblast, which is in turn required for the further differentiation, growth, and integrity of extraembryonic tissues.

\section{Outgrowths from homozygous Sox $2^{\text {Bgeo }}$ blastocysts and ICMs are abnormal}

Because the peri-implantation lethality makes it difficult to study details of the phenotype, blastocysts from Sox $2^{\text {Bgeo }}$ heterozygous intercrosses were grown in culture. Homozygous mutants were initially indistinguishable from wild-type or heterozygous embryos (Fig. 4A,E): They hatched from their zonae and attached to the plastic substratum, and trophectoderm grew and extended in an identical manner. However, by day 5 in culture none of the homozygotes showed the typical well-developed ICM-derived structures seen in the majority of wild-type and heterozygous outgrowths (Fig. 4F-H and 4B-D, respectively). Apart from trophectoderm, the only other obvious cell type present in the mutants resembled PE (Fig. 4F-H), which was confirmed by the expression of tissue plasminogen activator (tPA; Fig. 4I; Table 2; Marotti et al. 1982).

The primary defect of the cultured mutant embryos appeared to be in the epiblast, consistent with the in vivo phenotype. As predicted, markers of epiblast, such as Oct4 and Fgf4, are lost progressively and coordinately from cultures of normal embryos as the ICM differentiates into a variety of cell types (Fig. 4I; Table 2). The

Table 2. Expression of early embryonic markers in blastocysts and cultured outgrowths from Sox $2^{\text {Bgeo }}$ heterozygous intercrosses

\begin{tabular}{|c|c|c|c|c|c|c|c|}
\hline \multirow[b]{2}{*}{ Sample } & \multirow[b]{2}{*}{ Genotype } & \multirow[b]{2}{*}{ Total no. } & \multirow[b]{2}{*}{ Phenotype } & \multicolumn{4}{|c|}{ RT-PCR } \\
\hline & & & & Sox2 RNA & Oct4 RNA & Fgf4 RNA & $t P A$ RNA \\
\hline \multirow[t]{2}{*}{ Blastocysts } & $+/+$ or $+/-$ & 19 & Normal & 18 & $\mathrm{nd}^{\mathrm{a}}$ & 16 & nd \\
\hline & $-1-$ & 7 & Normal & $2^{\mathrm{b}}$ & nd & 6 & nd \\
\hline \multirow[t]{4}{*}{3 day o.g. } & $+1+$ or $+/-$ & 3 & Normal & 3 & 2 & 1 & 3 \\
\hline & $+/+$ or $+/-$ & 4 & Abnormal & 3 & 1 & 0 & 3 \\
\hline & $-1-$ & 1 & Normal & $1^{\mathrm{b}}$ & 1 & 0 & 1 \\
\hline & $-1-$ & 2 & Abnormal & $2^{\mathrm{b}}$ & 2 & 0 & 2 \\
\hline \multirow[t]{3}{*}{7 day o.g. ${ }^{\mathrm{d}}$} & $+/+$ or $+/-$ & 5 & Normal & 5 & 4 & 3 & 5 \\
\hline & $+/+$ or $+/-$ & 13 & Abnormal & 6 & 4 & 6 & 13 \\
\hline & $-/-$ & 6 & Abnormal & $2^{b}$ & 1 & 0 & 5 \\
\hline
\end{tabular}

\footnotetext{
${ }^{a}$ nd, not determined.

${ }^{\mathrm{b}}$ Trace amounts detected, most likely from contamination from the polar body, supernumerary sperm, or serum.

co.g., cultured blastocyst outgrowths.

dEmbryos were cultured with human recombinant FGF4 and heparin.
} 


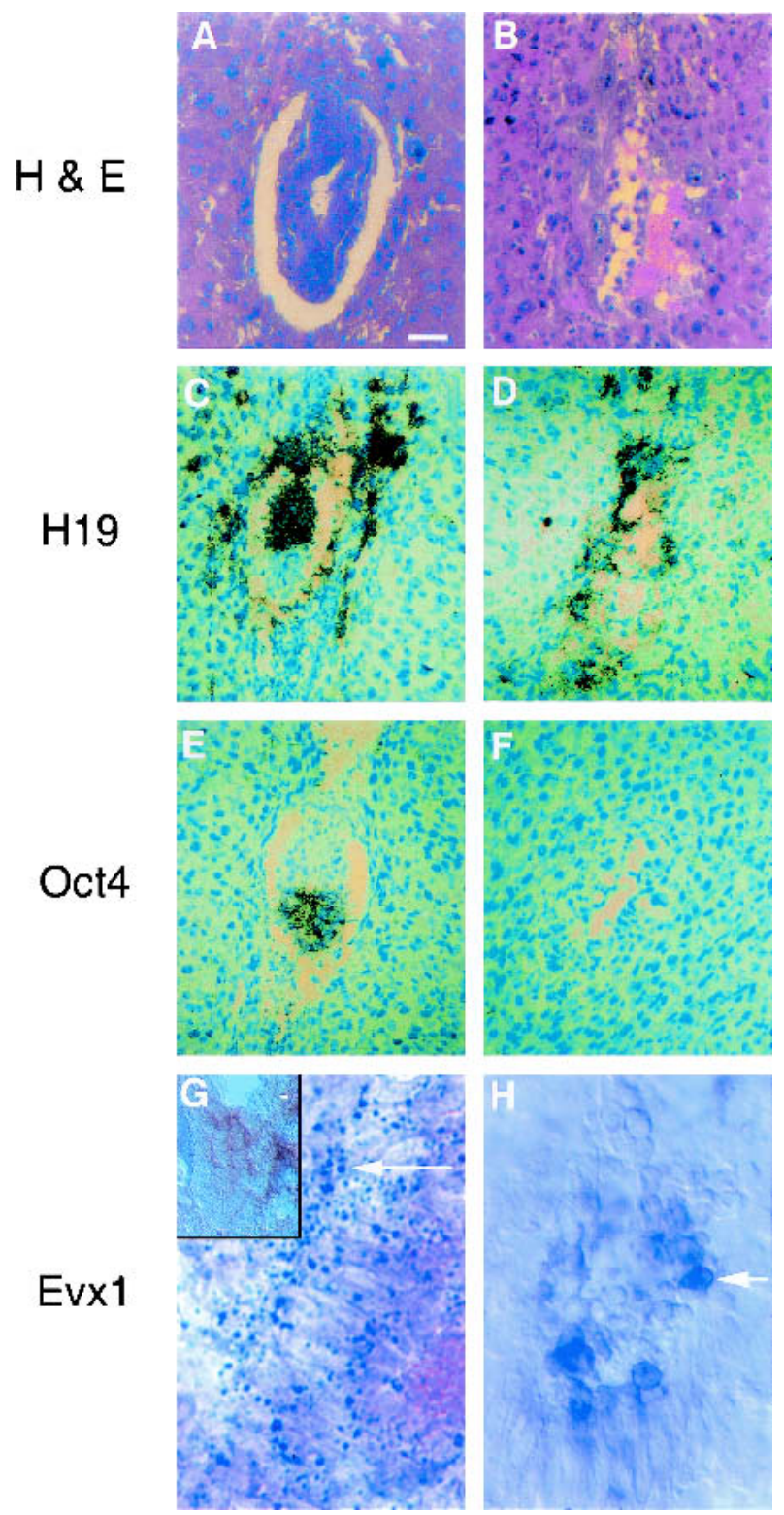

Figure 3. Sox $2^{\beta g e o}$ mutant embryos lack epiblast. $(A-H)$ Histological and marker analysis of 6.0-dpc embryos from Sox $2^{\beta g e o}$ intercrosses. $(A, C, E, G)$ Normal embryos. $(B, D, F, H)$ Mutant embryos. Sections were stained with haemotoxylin and eosin $(\mathrm{H} \&$ E) in $A$ and $B$. RNA in situ hybridization was performed for $H 19$ (extraembryonic marker; $C, D$ ), Oct4 (epiblast marker; $E, F$ ), and Evx1 (VE marker; $G, H$ ). ${ }^{35}$ S-UTP-labeled probes were used for $H 19$ and Oct4, and sections were counterstained with methyl green. A DIG-labeled probe was used for Evx1. The arrows shown in the main panel and inset of $G$ refer to the same region. Evx1 staining in the wild-type embryo is distal to the embryonic/extraembryonic border as expected $(G)$ and appears more punctate because the cells are flatter than those in the mutant embryo $(H)$. Sox $2^{\beta g e o}$ null embryos form disorganized extraembryonic tissues, but do not form epiblast. Bars: $A, B, 50 \mu \mathrm{m} ; C-F$, $65 \mu \mathrm{m} ; G$ (inset), $75 \mu \mathrm{m} ; G, H, 30 \mu \mathrm{m}$.

homozygous mutants showed weak Oct4 expression at day 3, but by day 7 all except one were negative. Fgf4 expression was, however, never seen in homozygote out- growths despite being present in blastocysts at $3.5 \mathrm{dpc}$. If SOX2 does regulate Fgf4, and if it is the only critical target gene, the Sox2 null embryos should be rescued by adding FGF4, as shown for Fgf4 null mutant blastocysts in vitro (Feldman et al. 1995). However, it had no effect (Table 2; data not shown).

Oct4 mutant ICMs grown in culture aberrantly give rise to trophoblast cells instead of epiblast or ExEn (Nichols et al. 1998). We therefore looked at the fate of ICMs isolated by immunosurgery (Solter and Knowles 1975) from Sox $2^{\beta g e o}$ null blastocysts and found that they could also divert into the trophoblast lineage (Fig. 4P,Q), as seen by positive staining for the terminally differentiated trophoblast primary giant cell marker, placental lactogen 1 (P11; Colosi et al. 1987). Predictably, wild-type and Sox $2^{\beta g e o}$ heterozygous ICM outgrowths were unable to form trophectoderm as shown by a failure to express P11 (RNA in situ, $\mathrm{n}=6$ for each genotype) and were mainly composed of round or flat fibroblast-like cells indicative of $\mathrm{PE}$ and other presumably epiblast derived cells (Fig. 4N,O). In the mutant outgrowth shown in Figure $4 \mathrm{P}$, only Pl1-positive cells are present; however, other cell types were usually found (Fig. 4Q). The P11negative cells resemble diploid trophoblast and PE. Consistent with this, RT-PCR analysis showed that null ICM outgrowths express Ascl2 and $t P A$, typical of diploid trophoblast and PE, respectively (data not shown). All but one of the eight mutant ICM outgrowths analyzed expressed Pl1 (RNA in situ, $\mathrm{n}=5$; RT-PCR, $\mathrm{n}=3$ ).

\section{Maternal SOX2 protein persists throughout preimplantation development}

SOX2 was found in the ICM at blastocyst stages (Fig. $5 \mathrm{~A}-\mathrm{C})$, in which the protein was primarily nuclear as shown by antibody staining on isolated ICMs (Fig. 5G-I). The intact blastocysts also revealed the presence of SOX2 in trophectoderm, but here the protein was only cytoplasmic (Fig. 5B). Confocal microscopy using affinity-purified antibody confirmed these results, as did experiments with an independently derived anti-SOX2 peptide antibody (data not shown). Finding SOX2 in trophectoderm was unexpected as transcripts were not detected in these cells by RNA in situ hybridization (Fig. 1A). Confocal microscopy was also used to compare SOX2 staining with that of OCT4 in fully expanded blastocysts. As expected, OCT4 was exclusively nuclear in the ICM, whereas SOX2 was mostly nuclear, but some cytoplasmic staining was seen (Fig. 5J-L). As previously reported, OCT4 was seen in the layer of cells adjacent to the blastocoel, presumed to be primitive endoderm (Palmieri et al. 1994; Nichols et al. 1998), and absent from trophectoderm, unlike SOX2 (Fig. 5K,L).

These results suggest that much of the protein in a blastocyst corresponds to long-lived maternal protein laid down in the growing oocyte (Fig. 1G,I), rather than it being a product of zygotic transcription. To explore this further, antibody staining was carried out between the 1-cell and blastocyst stages. Confocal and conventional 
$(+/+)$
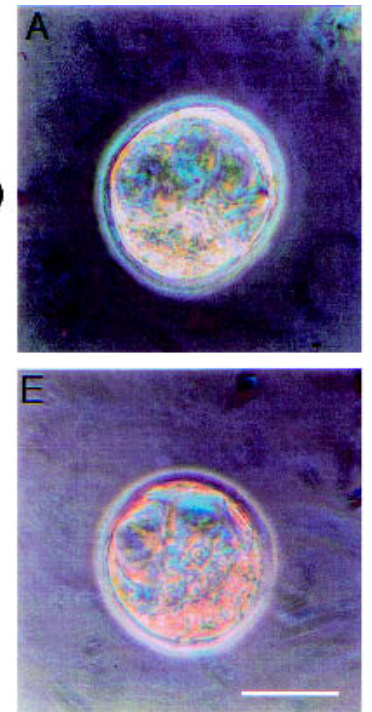

(+/+)

J
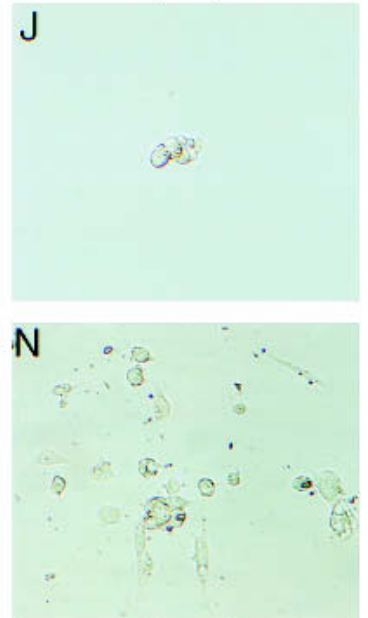
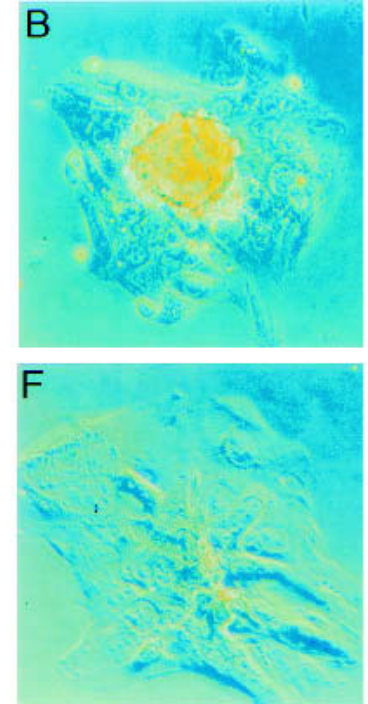

(+/-)

K

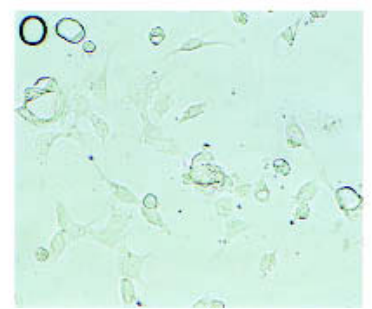



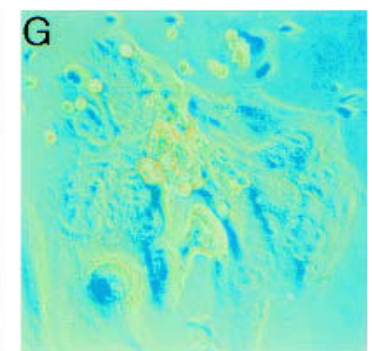

$(-1-)$

L

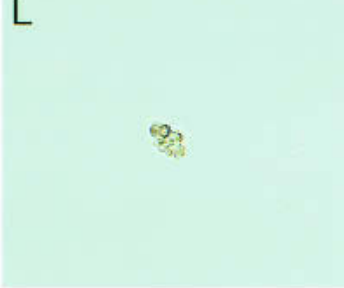

P



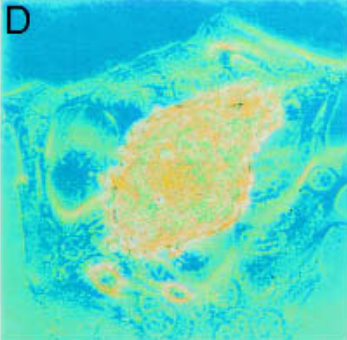

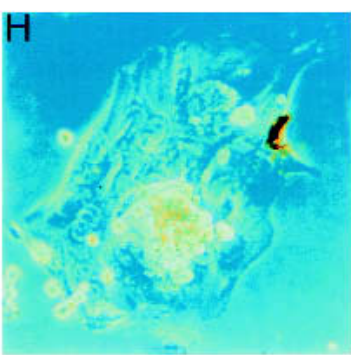

$(--)$

M

बis

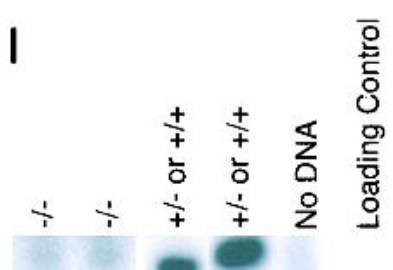

Sox2

- - O Oct4

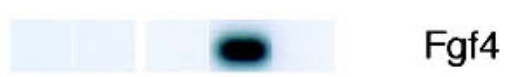

-0 tPA

000100

Figure 4. Sox $2^{\beta g e o}$ null blastocysts show defective ICM development in culture. $(A-H)$ Phase contrast microscopy of embryos from Sox $2^{\beta g e o}$ intercrosses, with wild-type $(+/+; A)$ and Sox $2^{\beta g e o}$ null $(-/-; E)$ blastocysts and different blastocyst outgrowths grown in culture for $3 \mathrm{~d}(B-D, F-H)$. Wild-type and mutant blastocysts look similar, but the ICM of null blastocysts fails to outgrow. (I) RT-PCR marker analysis of Sox $2^{\beta g e o}$ null blastocyst outgrowths. Morulae from Sox $2^{\beta g e o}$ heterozygous intercrosses were cultured for $5 \mathrm{~d}$. BSC loading control refers to Bluescript RNA that was not added to an RNA preparation, but added directly to the subsequent RT reaction. No DNA refers to the negative control used during the PCR reaction. (J-Q) P11 RNA in situ hybridization on Sox $2^{\beta g e o}$ null ICM outgrowths. Isolated ICMs $(J-M)$ were grown in culture for $4 \mathrm{~d}$ and analyzed for $P 11$ expression $(N-Q)$. Mutant $(P, Q)$ but not wild-type $(N)$ or Sox $2^{\beta g e o}$ heterozygous $(O)$ ICM outgrowths express PL1. Bars: $A, E, 35 \mu \mathrm{m} ; B-D, F-H, 100 \mu \mathrm{m} ; J-Q, 27 \mu \mathrm{m}$. 
fluorescence microscopy gave similar results, but only the former are shown. SOX2 was found throughout the fertilized egg (Fig. 5M,R), but its translocation into nuclei was clearly evident at the 2-cell stage (Fig. $5 \mathrm{~N}, \mathrm{~S}$ ). It was primarily nuclear in all cells by the 6-8-cell stage, although there was still some cytoplasmic staining (Fig. $5 \mathrm{O}, \mathrm{T}$ ), and the same was true after compaction (Fig. $5 \mathrm{P}, \mathrm{U})$. In the late morula, however, the outer layer of cells showed diffuse staining (Fig. 5Q,V), and in early blastocysts SOX2 was uniquely cytoplasmic in trophectoderm cells, but mostly nuclear in the ICM (Fig. 5B; data not shown). Additionally, SOX2 was absent from the polar body (Fig. $5 \mathrm{~N}, \mathrm{~S}$ ).

We next looked for SOX2 in blastocysts from Sox $2^{\text {Bgeo }}$ heterozygous intercrosses, of which $25 \%$ are expected to be homozygous mutants and could not contain SOX2 unless it were maternally derived. However, among 27 embryos stained with horseradish peroxidase, all looked identical within each of the three litters analyzed, whereas controls with preimmune sera showed no staining (Fig. 5W, panels 1-3). Comparable results were obtained using fluorescent antibody staining on isolated ICMs $(\mathrm{n}=30)$ and on whole blastocysts $(\mathrm{n}=30)$, using an affinity-purified antibody and confocal microscopy, in which, again, similar patterns of nuclear and cytoplasmic staining were seen in all embryos (data not shown). Collectively, these data are consistent with the notion that SOX2 accumulates in the cytoplasm of growing oocytes and persists in all cells at least until the blastocyst stage, when it is exported from the nuclei of trophectoderm cells.

\section{Early lethality of Sox $2^{\text {Bgeo }}$ mutants is rescued by wild-type ES cells}

From marker analysis in utero and in explant cultures, it seems likely that the mutant embryos die because of a defect of the epiblast shortly after implantation. However, at egg cylinder stages, Sox2 expression is not confined to the epiblast, but also initiates in an adjacent region of the ExE important for patterning the embryo (Fig. 1B). The lack of Sox2 in the ExE could therefore be partly or wholly responsible for the phenotype. We therefore asked whether the postimplantation lethality could be rescued by the introduction of wild-type ES cells into mutant blastocysts. ES cells will contribute to all epiblast derivatives, but are excluded from ExE (Beddington and Robertson 1989).

CCE, ROSA26, or B5/EGFP ES cells were injected into blastocysts from Sox $2^{\text {Bgeo }}$ intercrosses. To distinguish retrospectively the genotype of the host blastocyst, in situ hybridization was used to look for Sox2 transcripts in resulting postimplantation embryos. Nine (19\%) of 48 embryos analyzed between 7.5 and $8.0 \mathrm{dpc}$ showed no staining in the chorion and must correspond to Sox $2^{\text {Bgeo }}$ homozygous hosts (Fig. 6). Figure 6A shows an example of such a 7.5-dpc chimeric embryo, beside one obtained using a wild-type or heterozygous host. We conclude that the ES cells rescue the Sox $2^{\text {Bgeo }}$ null phenotype by contributing to the epiblast and thereby allowing sur- vival beyond implantation. Because ES cells only colonize epiblast derivatives (as shown by the distribution of EGFP-positive derivatives of B5 cells), it follows that the defect in nonchimeric Sox $2^{\beta g e o}$ null embryos is in the epiblast.

At later stages it was possible to genotype chimeras directly from yolk sac endoderm. Of 40 embryos analyzed between 10.5 and $11.5 \mathrm{dpc}, 24(60 \%)$ were derived from Sox $2^{\text {Bgeo }}$ heterozygotes, whereas $16(40 \%)$ were from wild-type host blastocysts. No embryos obtained from homozygous hosts were recovered at this time, nor any at $8.5 \mathrm{dpc}$. However, embryonic development is normal to at least $12.5 \mathrm{dpc}$ when tetraploid host embryos are used to make chimeras with any of the three ES cell lines we used (Hadjantonakis et al. 1998; data not shown). As tetraploid cells are excluded from epiblast-derived tissues, the latter are entirely ES-cell-derived. The failure of the Sox $2^{\beta g e o}$ homozygote $\leftrightarrow$ ES cell chimeras to survive after $7.5 \mathrm{dpc}$ must therefore reflect either a subsequent requirement for SOX2 in extraembryonic tissues, or a later defect in the embryo itself, which might be expected if it contained a significant proportion of mutant cells. To investigate the latter, the embryonic portion was dissected from chimeras made with B5/EGFP ES cells and stained for lacZ to reveal Sox $2^{\text {Bgeo }}$-expressing cells (Fig. 6B,E,H), whereas EGFP expression showed the degree of chimerism. The absence of Sox2 in the chorion was used to identify mutant hosts (Fig. 6A,F,I), and Msg1, a chorionic and VE marker (Dunwoodie et al. 1998), was used as a control for intact RNA (Fig. 6D,G,J). About $50 \%$ of chimeras made with mutant host embryos exhibited some cells positive for lacZ. An example is shown in Figure 6E, in which there is faint staining in the anterior region, corresponding to neuroectoderm. Staining was also evident on the surface, in the proximal anterior region, which represents expression of Sox $2^{\text {Bgeo }}$ within the VE layer. We have never seen expression of the lacZ reporter in ExEn in any Sox $2^{\text {Bgeo }}$ heterozygous embryos (Fig. 2), implying that in the complete absence of SOX2, some homozygous Sox $2^{\text {Bgeo }}$ cells within the epiblast have differentiated into VE and still retain residual $\beta$-galactosidase activity. Chimeras with Sox $2^{\text {Bgeo }}$ heterozygous host embryos had a mixed epiblast with varying proportions of GFP-positive cells and mottled lacZ staining in neuroectoderm.

Only a few cells in the Sox $2^{\beta g e o}$ null chimeras expressed lacZ within prospective neuroectoderm. We do not know if these cells truly correspond to neuroectoderm, but the null cells are clearly disadvantaged compared with wild-type cells, and there are probably too few to cause lethality after $7.5 \mathrm{dpc}$. Moreover, half the chimeras showed no lacZ staining and widespread expression of EGFP, indicating that the epiblast was entirely ES-cell-derived. These results indicate a cell-autonomous requirement for SOX2 within cells of the epiblast. However, they also imply that the chimeras fail to survive much beyond 7.5 dpc owing to an extraembryonic rather than embryonic defect.

ES cells are similar to epiblast, with high levels of SOX2 protein in their nuclei (Fig. 6K,L), whereas tropho- 
blast stem (TS) cells represent a self-renewing population of cells in the ExE that require FGF4 for survival and maintenance (Tanaka et al. 1998). It is the rapidly dividing cells in the chorion that express Sox2. Therefore, if Sox2 is required independently in both embryonic and ExE lineages, then it should not be possible to derive either ES or TS cell lines from homozygous Sox $2^{\beta g e o}$ embryos. Indeed, we were unable to derive homozygous mutant ES cells either directly from blastocyst outgrowths (see above) or by selection of heterozygous ES cells using high G418 concentrations (Mortensen et al. 1992). Similarly, we failed to obtain any homozygous Sox $2^{\text {Bgeo }}$ TS cell lines from blastocyst outgrowths, yet we were able to establish both wild-type $(71 \%)$ and heterozygous lines (29\%) that expressed appropriate markers, for example, Fgfr2 (Supplementary Fig. 1). Additionally, we found that wild-type TS cells express Sox2 RNA (Supplementary Fig. 1) and contain protein, which is mostly nuclear (Fig. 6P). SOX2 is down-regulated upon differentiation after FGF4 withdrawal, although the protein persists in some cells (Fig. 6P). The expression of SOX2 in TS cells, ExE, and chorion, and the inability to generate TS cells lacking the gene, provides further evidence that it plays a critical role in the development of the placenta.

\section{Discussion}

\section{Early embryonic lethality of Sox $2^{\text {Bgeo }}$} homozygous mutants

Essential requirement for Sox 2 in epiblast development Sox 2 and Oct4 expression overlap during early embryogenesis in the morula, ICM, epiblast, and germ cells. This suggests parallel roles for the two factors in the maintenance of pluripotentiality (Pesce and Schöler 2000). The phenotypic consequences of the targeted disruption of Oct4 reveal that it is required for the first cell fate decision, as all mutant ICM cells are diverted to a trophectoderm fate (Nichols et al. 1998). The present study shows that zygotic Sox2 expression is also required for the ICM/epiblast lineage, but this is not revealed until after implantation, presumably when maternal SOX2 protein becomes diluted out through the rapid growth of the embryo. In the absence of SOX2, there is no equivalent rapidly proliferating cell population, the only surviving cells being trophoblast giant cells and ExEn. This is seen with explants as well as in vivo. The primary defect was in the epiblast as shown by rescue of mutant embryos to $7.5 \mathrm{dpc}$ by injection of wild-type ES cells. In many of these chimeras the entire embryo was derived from the ES cells, revealing the defect to be cell-autonomous to the epiblast. Consistent with this, we were unable to derive ES cells homozygous for Sox $2^{\text {Bgeo }}$.

What is the fate of the mutant epiblast cells? We see no increase in cell death (data not shown), but it is possible that SOX2 is required for their proliferation. A few lacZ-positive cells were seen within the embryonic portion of some of the ES-cell-rescued chimeras, which could represent mutant cells that have failed to proliferate, surviving among an otherwise wild-type epiblast. Alternatively, SOX2 could be essential for epiblast cell identity, and in its absence the cells could differentiate into another cell type. We favor this second alternative for several reasons. In normal embryos, as shown by chimera studies, lineage analysis, and in vitro culture, the ability to form trophoblast is lost from the ICM by the early blastocyst stages. However, ICMs isolated from Sox $2^{\beta g e o}$ homozygotes gave rise to trophoblast giant cells in culture. This respecification into trophoblast also occurs in blastocysts or ES cells lacking Oct4 (Nichols et al. 1998; Niwa et al. 2000), but in contrast, in the presence of exogenous FGF4, Oct4 mutant trophectoderm proliferates to produce TS cells, whereas FGF4 had no discernible effect on trophoblast derived from Sox $2^{\beta g e o}$ null blastocysts.

Homozygous Sox $2^{\beta g e o}$ embryos also differ from Oct4 mutants, in that they readily formed ExEn. This was seen in cultures of isolated ICMs or whole blastocysts and after implantation of mutant embryos or ES-cellrescued chimeras. ExEn is thought to be generated only once in the blastocyst and not from later epiblast (Gardner 1985). Cells of the ICM/epiblast lineage are therefore likely to survive in the Sox $2^{\text {Bgeo }}$ mutants at least to the stage when primitive endoderm normally differentiates, presumably owing to the persistence of maternal protein. As shown by histology and marker analysis, epiblast cells were lost from mutant embryos after implantation, although there was often a substantial mass of ExEn in addition to some trophoblast giant cells. Although VE (EVX1-positive) cells were present, the ExEn is mostly parietal ( $t P A$ positive), which is expected, as this will differentiate from VE in the absence of contact with epiblast or ExE (Hendrey et al. 1995). The abundance of ExEn implies that it has continued to be generated after

Figure 5. Nuclear and cytoplasmic staining of SOX2 protein in preimplantation embryos. $(A-L)$ SOX2 antibody staining in wild-type blastocysts. Embryos were incubated in SOX2 $(B, H, L)$, preimmune $(\mathrm{PI} ; E)$, or OCT4 $(K)$ antiserum. Nuclei were stained with 7-AAD $(A, D, G)$ or DAPI $(J) .(C, F, I)$ Overlays of the antibody and 7-AAD staining to show colocalization in yellow. $(A-F)$ Whole blastocysts. $(G-I)$ An ICM isolated by immunosurgery. $(J-L)$ Confocal images, using an affinity-purified SOX2 antibody. SOX2 is observed throughout the ICM in the nucleus (n) and cytoplasm (line) unlike OCT4, which is detected only in the nucleus. The arrowhead indicates the layer of ExEn where OCT4 is present but SOX2 levels are low. $(M-V)$ SOX2 antibody staining in wild-type embryos from 1-cell to late morula (L-morula) stages. Embryos were stained for SOX2 using affinity-purified antibody (M-Q), and nuclei were visualized with DAPI $(R-V)$. All panels are confocal images. $\mathrm{n}$, nuclear staining; c, cytoplasmic staining; pb, polar body. $(W)$ SOX2 antibody staining in blastocysts from Sox $2^{\beta g e o}$ heterozygous intercrosses. Three separate litters were analyzed (1-3) using horseradish peroxidase and DAB staining. SOX2 is observed in all embryos. The last two embryos in each set are wild-type preimmune controls $\left(^{\star}\right)$. Bars: $A-F, J-L$, $25 \mu \mathrm{m} ; G-I, 30 \mu \mathrm{m} ; M-V, 25 \mu \mathrm{m} ; W, 80 \mu \mathrm{m}$. 
implantation. This is also suggested by finding cells positive for lacZ in the VE layer of the ES-cell-rescued chimeras at $7.5 \mathrm{dpc}$, whereas this has never been seen in a large number of heterozygous Sox $2^{\beta g e o}$ embryos (Fig. 2; data not shown). We have also seen lacZ staining in cells with the appearance of PE from mutant blastocyst outgrowths, but not in heterozygotes. As $\beta$-galactosidase is quite stable, transcription of $\beta g e o$ in mutant epiblast cells may well have given rise to lac $Z$ activity in their differentiated derivatives.
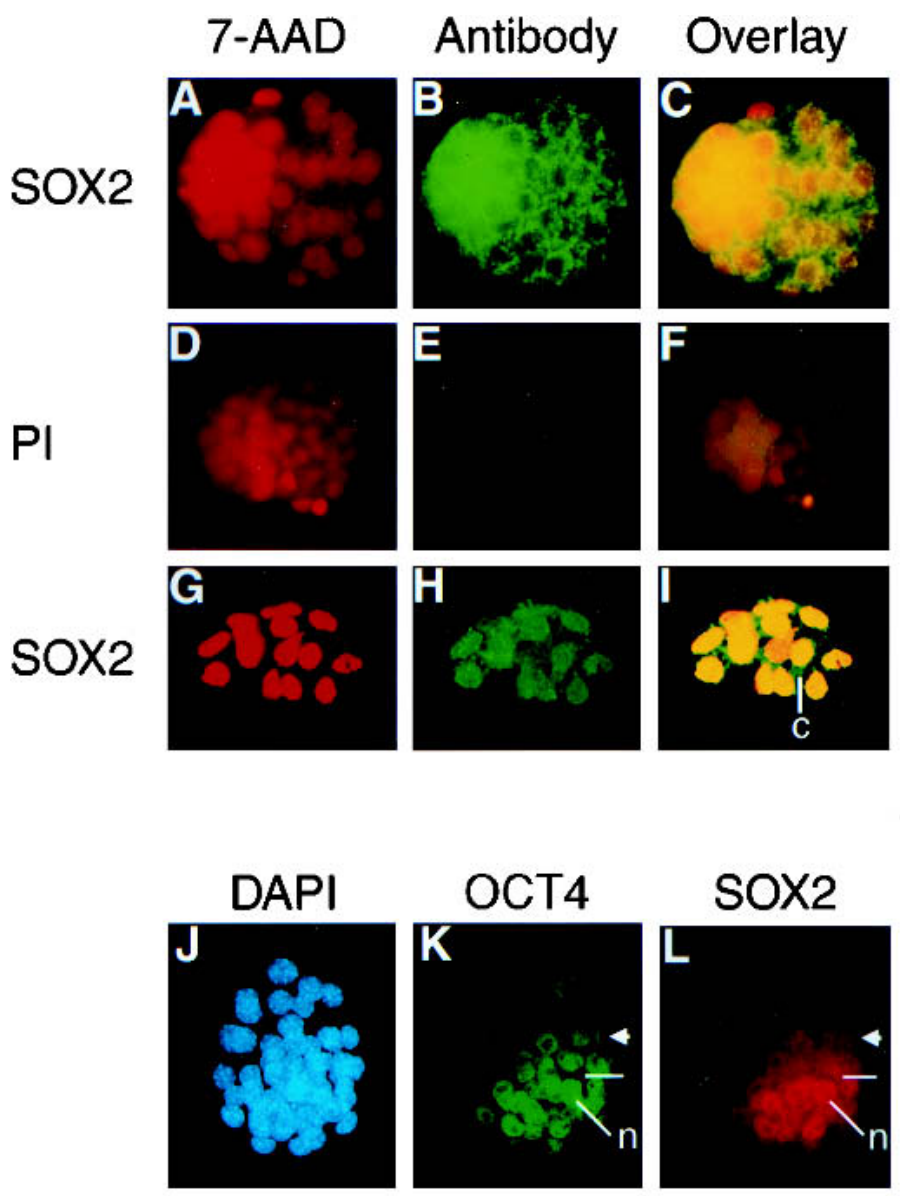

W

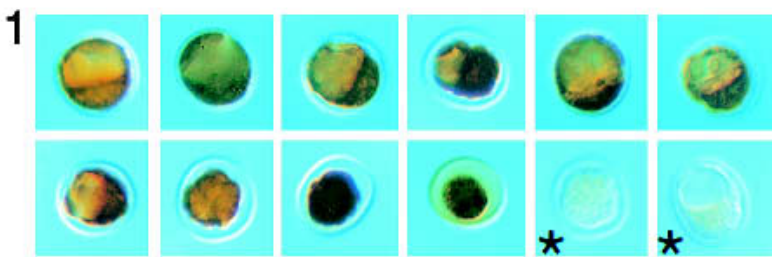

2
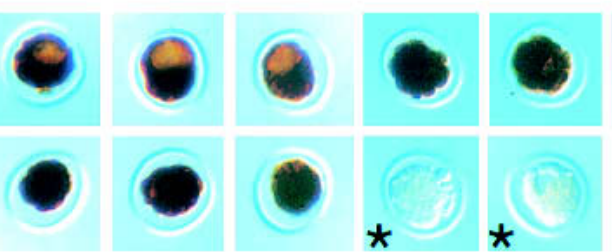

3
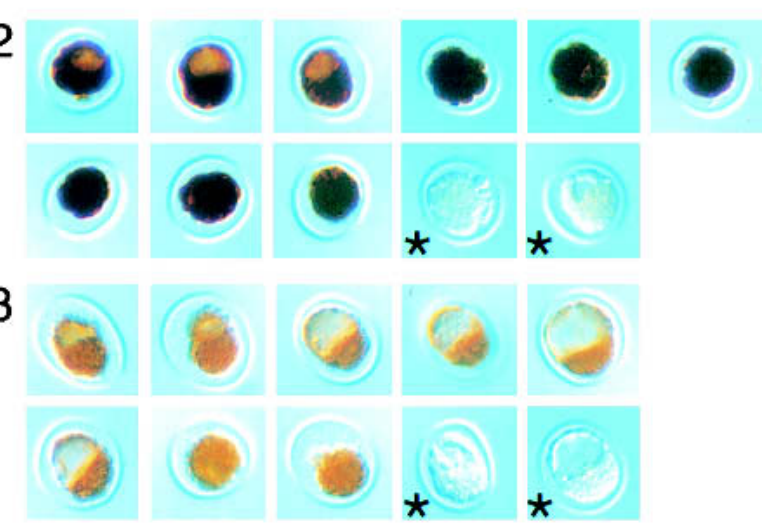

\section{1-cell}
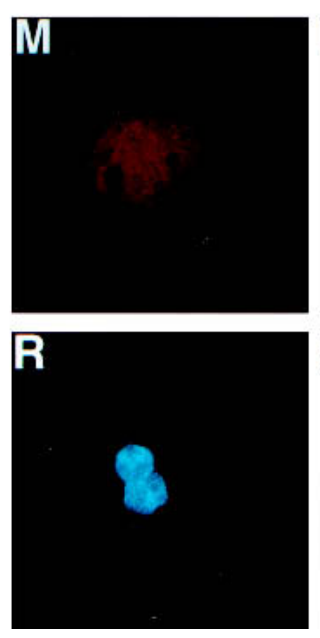
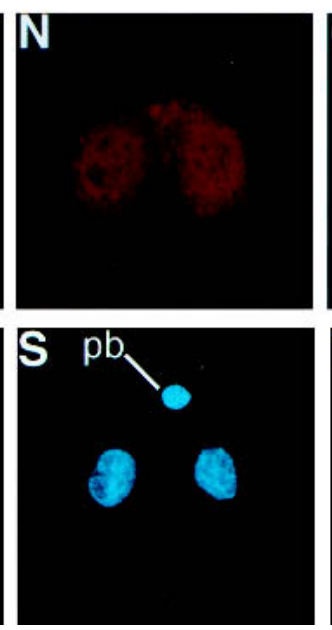
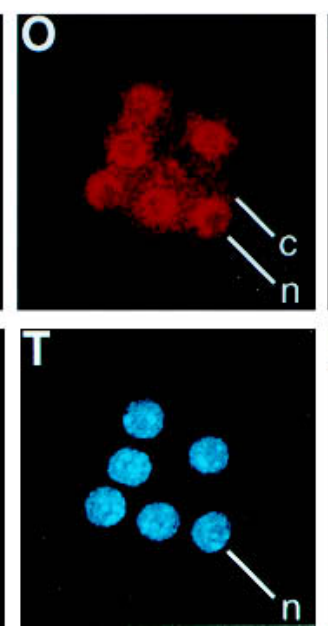

morula 25-30 cells

L-morula $35-40$ cells
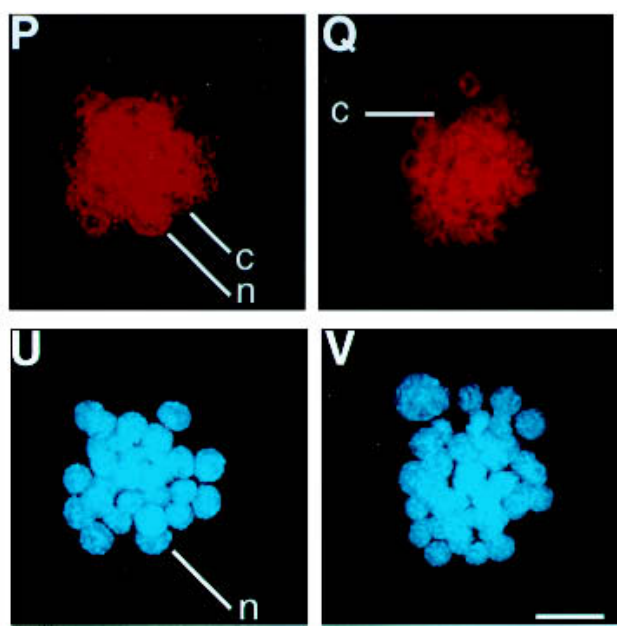

(Figure 5 legend on facing page) 


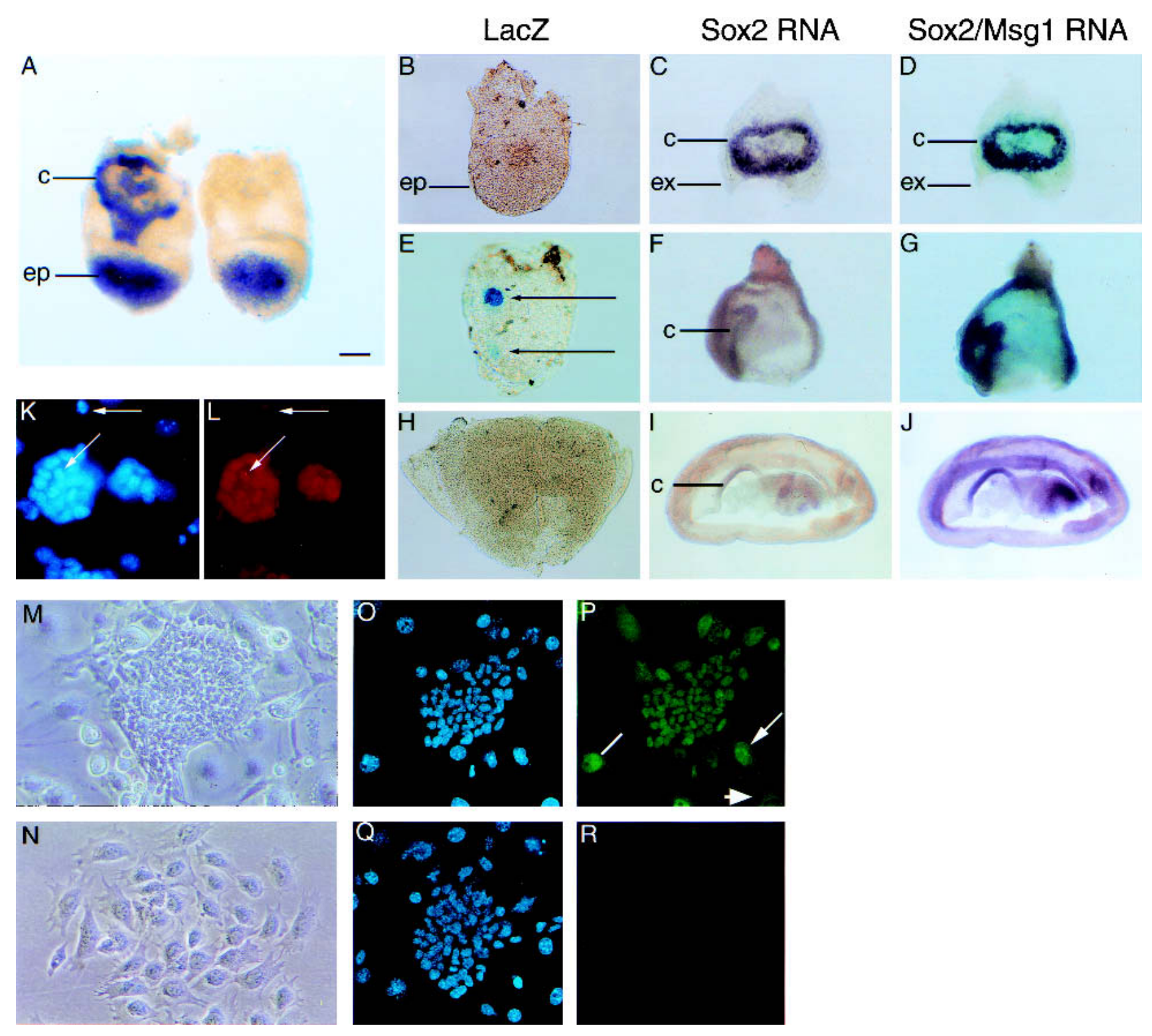

Figure 6. Chimera rescue of Sox $2^{\text {Bgeo }}$ homozygotes and the presence of SOX2 protein in TS cells. $(A)$ Sox2 RNA is absent in the chorion of a 7.5-dpc Sox $2^{\beta g e o}$ null homozygote rescued with wild-type ES cells (right) compared with a wild-type or heterozygote host embryo with chorionic (c) staining (left). (B-I) Chimeras were dissected to separate the embryo/epiblast (ep) from the extraembryonic region. The embryo was stained for lacZ $(B, E, H)$, and extraembryonic tissue was first analyzed for Sox2 RNA by in situ hybridization $(C, F, I)$ and then for $M s g 1$ as a positive control $(D, G, I) .(B-J)$ Chimeras corresponding to two rescued Sox $2^{\text {Bgeo }}$ homozygotes $(E-J)$ and a wild-type host (based on Sox2 chorionic expression and no lacZ staining; B-D). Arrows in $E$ show Sox $2^{\beta g e o}$ null cells expressing lacZ in a rescued chimera. $(K, L)$ SOX2 antibody staining in ES cells $(L)$, and nuclear staining with DAPI $(K)$. SOX2 is seen in the nucleus of ES cells $(L$, arrows), and is absent in STO feeder cells $(K$, large nuclei). $(M, N)$ Phase micrographs of TS cells $(M)$ and differentiated TS cells $(N)$ grown in the absence of FGF4 for $4 \mathrm{~d}$. $(O-R)$ SOX2 antibody staining in TS cells. SOX2 $(P)$, preimmune $(R)$, and DAPI $(O, Q)$ staining. SOX2 is expressed in the nucleus of TS cells (round colony). In the surrounding differentiating cells, SOX2 remains nuclear (line), nuclear and cytoplasmic (arrow), or is greatly reduced (arrowhead), depending on the degree of differentiation. Bars: $A, 125 \mu \mathrm{m}$; $B-J, 90 \mu \mathrm{m} ; K, L, 23 \mu \mathrm{m} ; M, N, 15 \mu \mathrm{m} ; O-R, 40 \mu \mathrm{m}$.

It seems likely, therefore, that SOX2 is required to maintain cells of the epiblast in an undifferentiated state, and in its absence they change their identity, becoming trophectoderm or ExEn. In contrast, early embryo cells or ES cells lacking OCT4 can only form trophectoderm derivatives (Niwa et al. 2000). It is possible that SOX2 and OCT4 function together to maintain the pluripotent state throughout early development, but Oct4 mutants fail earlier, prior to the generation of ExEn, because maternal protein does not persist beyond the two-cell stage (Palmieri et al. 1994).

Our observations can also be correlated with experiments showing that overexpression of Oct4 results in the differentiation of ES cells into ExEn (Niwa et al. 
2000). Sox $2^{\beta g e o}$ homozygotes will theoretically have higher levels of unassociated OCT4 than heterozygotes or wild-type embryos, because SOX2 will not be present to complex with OCT4. We propose that the presence of both factors is required for epiblast, but the transient up-regulation of OCT4 and accompanying down-regulation of SOX2 leads to an altered set of target genes being activated or repressed. It is this imbalance between the two factors in favor of OCT4 that could be the normal mechanism initiating ExEn differentiation.

A secondary essential requirement for Sox 2 in extraembryonic ectoderm Sox2 transcripts could not be detected in trophectoderm at blastocyst stages, but shortly after implantation Sox2 is expressed at high levels in a ring of ExE adjacent to the epiblast. This develops into chorionic ectoderm, which continues to express Sox2 and contains the progenitor cell population for all trophoblast derivatives. Sox2 therefore marks these progenitors as well as those of the epiblast that give rise to the embryo. TS cells, which we show also express Sox2, can be derived from ExE at these stages (Tanaka et al. 1998). In the absence of FGF4, TS cells differentiate into mature trophoblast cell types, and as they do so, SOX2 becomes cytoplasmic or is lost altogether. We were unable to derive homozygous mutant TS cells, suggesting that they have a cell-autonomous requirement for SOX2. However, chimeras lacking Sox2 in the chorion did survive until $7.5 \mathrm{dpc}$. The most likely explanation for this is functional redundancy with Sox3, which is coexpressed with Sox2 in ExE from $5.5 \mathrm{dpc}$. However, Sox3 is lost from the chorion by $8.0 \mathrm{dpc}$ (Wood and Episkopou 1999), the time at which the chimeras die.

There is accumulating evidence to indicate functional redundancy among the B1 subgroup of Sox genes. The phenotypes resulting from mutations in each of the three genes is limited to those sites at which only the mutant gene is expressed. For example, Sox1 mice show lens defects beginning precisely at the time when Sox2 is turned off, whereas areas of the CNS where both are expressed appear normal (Nishiguchi et al. 1998; Wood and Episkopou 1999). Our data on mutations in Sox3 are also consistent with redundancy. The strongest phenotypes are specific to sites at which the others are not expressed. Moreover, when gene targeting was used to replace the ORF of Sox3 with that of Sox2, the resulting mice were normal (M. Parsons, S. Brunelli, C. Wise, K. Rizzoti, M. Cohen-Tannoudji, L. Pevny, and R. LovellBadge, unpubl.; S. Brunelli, K. Rizzoti, and R. LovellBadge, unpubl.). This notion of functional redundancy between B1 Sox genes is also supported by experiments in Xenopus and Drosophila (Kishi et al. 2000; Overton et al. 2002). Because Sox2 is the earliest of the subfamily to be expressed in the mouse (Wood et al. 1998; A.A. Avilion, unpubl.), no similar gene is active sufficiently early in the epiblast to compensate for its loss, whereas Sox3 can do so transiently in ExE. However, the survival of a few Sox $2^{\beta g e o}$ null cells within the embryonic portion of the ES-cell-rescued chimeras could be explained by re- dundancy with Sox3, which is expressed in epiblast from $6.0 \mathrm{dpc}$.

\section{SOX2 and Fgf4 regulation}

The phenotype of Sox $2^{\beta g e o}$ homozygotes is reminiscent of both Fgf4 and Fgfr2 mutant embryos, in that epiblast derivatives are missing and the only cells remaining from the trophectoderm lineage are trophoblast giant cells. This is consistent with the proposal by Ambrosetti et al. (2000) that SOX2 is required together with OCT4 for Fgf4 expression in early embryonic cells. However, there are several discrepancies. Directly at odds with the proposal is the presence of Fgf4 transcripts in almost all Sox $2^{\beta g e o}$ homozygous blastocysts. Moreover, the differentiation of ExEn is thought to be dependent on FGF4 signaling, as shown by its absence from Fgf4 and Fgfr2 mutant embryos and from studies of $\mathrm{Fgft}$ null ES cells (Wilder et al. 1997), yet Sox2 mutants readily give rise to ExEn in explant cultures and after implantation. ExEn is not seen in Oct4 mutants, although these fail at a stage prior to primitive endoderm formation. Consequently, the Sox2 mutants must express FGF4 at least to the point where primitive endoderm is induced. This is most likely owing to the persistence of maternal SOX2 protein.

The failure to rescue the ICM from Sox $2^{\beta g e o}$ homozygous blastocysts by exogenous FGF4, or in chimeras by wild-type ES cells, supports the argument that additional targets for SOX2 are required within the ICM/epiblast lineage. The same is true of OCT4 (Nichols et al. 1998), and there is evidence that the two transcription factors cooperate in the regulation of several other genes, such as Utf1 and Osteopontin, and possibly the autoregulation of Sox2 itself (Botquin et al. 1998; Nishimoto et al. 1999; Tomioka et al. 2002).

\section{SOX2 protein localization and persistence throughout preimplantation development}

Our data show that SOX2 is shuttled between the cytoplasm and nucleus during early embryogenesis. The protein is placed in the cytoplasm of growing oocytes, presumably to prevent it from acting in the nucleus, but this implies deliberate sequestration for its role postfertilization. Maternal SOX2 actively enters the nucleus by the 2-cell stage, but a mechanism for exporting it must operate in trophectoderm cells, where it is exclusively cytoplasmic. This all occurs independently of new Sox2 transcription, which begins in the late morula, as the protein is distributed identically in wild-type and homozygous mutant blastocysts. Recently a nuclear export signal has been found within the HMG box of several SOX proteins. SOX10 actively requires nucleocytoplasmic shuttling for transactivation of target genes in vitro (Rehberg et al. 2002), whereas sex reversal can be induced in cultured XX gonads using an inhibitor that results in nuclear sequestering of SOX9 (Gasca et al. 2002). SOX2 contains a similar putative export signal, and future experiments will address its function. 
Sox $2^{\beta g e o}$ homozygotes almost certainly survive as long as they do because of the presence of maternal SOX2 protein. Most maternal gene products are destroyed at the 2- or 8-cell stages (Howe and Solter 1979). However, the persistence of a few proteins up to blastocyst stages has been noted, including E-cadherin, $\beta$-catenin, the nucleopore protein CAN/nup24, and the transcription factor Max (Larue et al. 1994; Haegel et al. 1995; van Deursen et al. 1996; Shen-Li et al. 2000). As it is not required in differentiated trophoblast or in ExEn, SOX2 is the first oocyte-derived transcription factor we are aware of without a general housekeeping function that persists until implantation. During this time it appears to be involved in specifying the ICM/epiblast and ExE lineages, which begs the question whether proteins laid down in the oocyte, even if they are not localized asymmetrically, are required for patterning early mammalian development.

\section{Conclusions}

Our results on SOX2, together with those on OCT4 (Nichols et al. 1998; Niwa et al. 2000), suggest a simple combinatorial model to explain the establishment of the three cell lineages that arise in preimplantation development (Supplementary Fig. 2). Thus, both factors are required in the lineage leading to epiblast formation, and in their absence trophectoderm is formed. OCT4 alone is required to initiate ExEn development, and SOX2 alone is required for ExE. Because the ExEn appears normal in the chimeras rescued with wild-type ES cells, this suggests that this is the only lineage for which there is no cell-autonomous requirement for SOX2. Finally, we have shown that SOX2 is required for two stem cell types in the early embryo, and it also marks stem/precursor cell populations within the CNS. Comparing its role in these cells will help elucidate the nature of the stem cell state.

\section{Materials and methods}

\section{Gene targeting}

Sox2 genomic clones were isolated from a $129 /$ SvEv library using as probe an ApaI-HindIII restriction fragment $5^{\prime}$ to the HMG box of the cDNA (Collignon et al. 1996). The pSA $\beta$-geo targeting vector (Friedrich and Soriano 1991) was modified by removing the splice acceptor site at the $5^{\prime}$ end as an SpeI/HindIII fragment. A $12-\mathrm{kb}$ NotI fragment $5^{\prime}$ of Sox 2 was ligated to the $5^{\prime}$ end of the $\beta$-geo cassette, and a 2.5 -kb SalI $3^{\prime}$-Sox2 fragment was cloned adjacent to the polyadenylation sequence. The targeting vector was linearized with $K p n I$ and electroporated into CCE ES cells, and G418-resistant clones were isolated. Positive recombinants were identified by Southern blotting using a 3 '-SalI/ EcoRI external probe on an EcoRI digest. Correct targeting and single-copy integration were confirmed using both $5^{\prime}$ and neo probes on a BamHI digest (data not shown). Clones 71 and 91 produced germ-line chimeras. Most experiments used the B1 MF1 line from clone 71 .

\section{Expression studies}

Procedures for RNA in situ hybridization on sections and whole mounts (Wilkinson 1998) were modified for the chimera analy- sis to prevent sample loss (Avilion et al. 2000). Digoxigenin (DIG)-labeled Sox2 antisense RNA probe was transcribed by T3 RNA polymerase from a 750-bp AccI/XbaI cDNA subclone (4C) linearized with $X$ hoI. Details of other probes are in cited publications.

For $\beta$-galactosidase staining, embryos were fixed for $20-45$ min on ice in $2 \%$ paraformaldehyde (PFA) and $0.1 \%$ glutaraldehyde, or in 4\% PFA for 20 min for the chimera rescue experiment. Samples were rinsed 3 times in PBS and stained overnight at $37^{\circ}$ in $1 \mathrm{mg} / \mathrm{mL} \mathrm{X-Gal,} \mathrm{following} \mathrm{established} \mathrm{protocols} \mathrm{(Sanes}$ et al. 1986).

\section{Cell and embryo culture}

Morulae were collected by flushing oviducts with M2 medium (Sigma) and cultured on gelatin-coated plastic chamber slides (NUNC) in KSOM (Speciality Media) containing $100 \mathrm{U} / \mathrm{mL}$ penicillin and $100 \mu \mathrm{g} / \mathrm{mL}$ streptomycin, until blastocyst stages, when the medium was changed to Dulbecco's modified Eagle's medium supplemented with $10 \%$ fetal calf serum (FCS), $2 \mathrm{mM}$ L-glutamine, $0.1 \mathrm{mM}$ 2-mercaptoethanol, and antibiotics. The medium was changed every $2 \mathrm{~d}$. In the FGF4 rescue experiment, embryos were cultured for a total of 3 or $7 \mathrm{~d}$, with or without $100 \mathrm{ng} / \mathrm{mL}$ human recombinant FGF4 (Sigma) and $1 \mu \mathrm{g} / \mathrm{mL}$ heparin (Sigma). ICMs were cultured for $4 \mathrm{~d}$ in Glasgow Minimum Essential Medium (Sigma) supplemented with 20\% FCS, LIF $(1000 \mathrm{U} / \mathrm{mL})$, glutamine, mercaptoethanol, and antibiotics as above. TS cell lines were established and differentiated according to Tanaka et al. (1998).

\section{Chimera rescue}

CCE, ROSA26 (Varlet et al. 1997) or B5/EGFP (Hadjantonakis et al. 1998) ES cells (12-15) were injected into blastocysts obtained from Sox $2^{\beta g e o}$ intercrosses. Following transfer into pseudopregnant females, embryos were harvested between 7.5 and 11.5 dpc, and where possible visceral yolk sacs were dissected for genotyping the VE layer (Beddington and Robertson 1989).

\section{Immunocytochemistry}

Polyclonal antibody FB46, made against the C-terminal domain of SOX2 (Kamachi et al. 1995), was used at a dilution of 1:500 or 1:1000 if affinity-purified. OCT4 antiserum (Santa Cruz; sc5279) was used at 1:250. ICMs isolated according to Solter and Knowles (1975) were spun at $300 \mathrm{rpm}$ for $6 \mathrm{~min}$ in a Cytospin centrifuge to attach them to poly-lysine-coated slides. Blastocysts and ICMs were fixed in 4\% PFA on ice for $10 \mathrm{~min}$, whereas ovaries were fixed for $1 \mathrm{~h}$ and embedded in wax. TS and ES cells were fixed in MEMFA on ice for $1 \mathrm{~h}$.

Stem cells and ICMs were blocked for 30 or $60 \mathrm{~min}$ in staining solution ( $1 \%$ goat serum, $0.5 \%$ Triton X-100 in PBS) and incubated overnight with SOX 2 antibody at $4^{\circ}$. Samples were rinsed and incubated for $1 \mathrm{~h}$ in secondary antibody using either fluorescein-conjugated goat anti-rabbit anti-serum (Tago Immunologicals) diluted at 1:200, or Cy3-conjugated goat anti-rabbit antibody (Amersham) diluted 1:300. Nuclei were stained with DAPI (Sigma; $200 \mu \mathrm{g} / \mathrm{mL}$ ) or 7-aminoactinomycin D (7-AAD, Molecular Probes; $10 \mu \mathrm{g} / \mathrm{mL}$ ). Whole mounts on blastocysts were processed similarly except that $10 \%$ goat serum and 2 $\mathrm{mg} / \mathrm{mL}$ BSA were used in the buffer solution. Ovaries were stained for SOX2 as previously described (Kamachi et al. 1995), using a 1:250 dilution of horseradish peroxidase-conjugated goat anti-rabbit IgG (Sigma) as secondary antibody. Samples were visualized with $3^{\prime} 3^{\prime}$-diaminobenzidine tetrahydrochloride (Sigma), and counterstained with haematoxylin. Confocal im- 
ages were obtained using a Leica TCS SP microscope and TCSNT software. Six $0.5-\mu m$ digital images were merged to form each panel shown.

\section{$R N A$ preparation, reverse transcription, and $P C R$}

RNA was made according to the guanidinium thiocyanate procedure (Chomczynski and Sacchi 1987). As an internal control for the RNA preparation, $10 \mathrm{fg}$ of an in vitro transcribed RNA derived from the polylinker of Bluescript SK (Stratagene) was added to each sample at the start of the preparation. For blastocyst RNA, the zona pellucida was removed with acid Tyrode's solution, and cells were lysed by heating at $90^{\circ}$ for $10 \mathrm{~min}$ in 20 $\mu \mathrm{L}$ of water. RNA was reverse-transcribed with Superscript II RNase H- Reverse Transcriptase (GIBCO-BRL) and primed with $1 \mu \mathrm{g}$ of random hexanucleotides (Pharmacia). PCR reactions were prepared using $0.2 \mathrm{U} / \mu \mathrm{L}$ Taq Polymerase, standard PCR conditions, and $1 \mathrm{M}$ betaine. For the RT-PCR blastocyst outgrowth marker analysis, $0.3 \mu \mathrm{L}$ of $\left[\alpha-{ }^{32} \mathrm{P}\right] \mathrm{dCTP}$ (Amersham; $3000 \mathrm{Ci} / \mathrm{mmole}$ ) was included in the reaction. Samples were amplified in the linear range in a Hybaid OmniGene thermocycler using one denaturation cycle at $94^{\circ}$ for $3 \mathrm{~min}$, followed by 25-40 amplification cycles, of one round at $94^{\circ}$ for $45 \mathrm{sec}$, annealing for $45 \mathrm{sec}$, and $72^{\circ}$ for $1 \mathrm{~min}$. A final extension step at $72^{\circ}$ for 5 min was performed. (For details, see Supplementary Material.)

\section{Acknowledgments}

We are grateful to Kat Hadjantonakis and Andras Nagy for the B5/EGFP ES cells and Liz Robertson for ROSA26 ES cells; Tilo Kunath and Janet Rossant for probes and advice on establishing TS cells; Austin Smith, Sally Dunwoodie, and Rosa Beddington for probes; and Vasso Episkopou for the SOX2 anti-peptide antibody. We also thank Vasso Episkopou and members of the laboratory and Institute, especially, Donald Bell, Silvana Guioli, Clare Wise, Karine Rizzoti, and Bill Buaas for critical reading of the manuscript, insightful ideas, and encouragement. This work was supported by the MRC and Louis Jeantet Foundation. A.A.A. is a recipient of a Burroughs Wellcome/Hitchings-Elion postdoctoral fellowship. S.K.N. was supported by fellowships from EMBO, the EU, the ESF, and the Telethon Foundation.

The publication costs of this article were defrayed in part by payment of page charges. This article must therefore be hereby marked "advertisement" in accordance with 18 USC section 1734 solely to indicate this fact.

\section{References}

Ambrosetti, D.C., Schöler, H.R., Dailey, L., and Basilico, C. 2000. Modulation of the activity of multiple transcriptional activation domains by the HMG and POU domains mediates the synergistic action of Sox 2 and Oct- 3 on the FGF- 4 enhancer. J. Biol. Chem. 275: 23387-23397.

Arman, E., Haffner-Krausz, R., Chen, Y., Heath, J.K., and Lonai, P. 1998. Targeted disruption of fibroblast growth factor (FGF) receptor 2 suggests a role for FGF signaling in pregastrulation mammalian development. Proc. Nat1. Acad. Sci. 95: 50825087.

Avilion, A.A., Bell, D.M., and Lovell-Badge, R. 2000. Microcapillary tube in situ hybridisation: A novel method for processing small individual samples. Genesis 27: 76-80.

Beddington, R.S.P. and Robertson, E.J. 1989. An assessment of the developmental potential of embryonic stem cells in the midgestation embryo. Development 105: 733-737.

Botquin, V., Hess, H., Fuhrmann, G., Anastassiadis, C., Gross,
M.K., Vriend, G., and Schöler, H.R. 1998. New POU dimer configuration mediates antagonistic control of an osteopontin preimplantation enhancer by Oct-4 and Sox-2. Genes \& Dev. 12: 2073-2090.

Chomczynski, P. and Sacchi, N. 1987. Single-step method of RNA isolation by acid guanidinium thiocyanate-phenolchloroform extraction. Anal. Biochem. 162: 156-159.

Collignon, J., Sockanathan, S., Hacker, A., Cohen-Tannoudji, M., Norris, D., Rastan, S., Stevanovic, M., Goodfellow, P.N., and Lovell-Badge, R. 1996. A comparison of the properties of Sox- 3 with Sry and two related genes, Sox-1 and Sox-2. Development 122: 509-520.

Colosi, P., Talamantes, F., and Linzer, D.I. 1987. Molecular cloning and expression of mouse placental lactogen I complementary deoxyribonucleic acid. Mol. Endocrinol. 1: 767776.

Dunwoodie, S.L., Rodriguez, T.A., and Beddington, R.S.P. 1998. Msg1 and Mrg1, founding members of a gene family, show distinct patterns of gene expression during mouse embryogenesis. Mech. Dev. 72: 27-40.

Dush, M.K. and Martin, G.R. 1992. Analysis of mouse Evx genes: Evx-1 displays graded expression in the primitive streak. Dev. Biol. 151: 273-287.

Feldman, B., Poueymirou, W., Papaioannou, V.E., DeChiara, T.M., and Goldfarb, M. 1995. Requirement of FGF-4 for postimplantation mouse development. Science 267: 246249.

Friedrich, G. and Soriano, P. 1991. Promoter trap in embryonic stem cells: A genetic screen to identify and mutate developmental genes in mice. Genes \& Dev. 5: 1513-1523.

Gardner, R.L. 1985. Regeneration of endoderm from primitive ectoderm in the mouse embryo: Fact or artifact? J. Embryol. Exp. Morph. 88: 303-326.

Gasca, S., Cañizares, J., de Santa Barbara, P., Méjean, C., Poulat, F., Berta, P., and Boizet-Bonhoure, B. 2002. A nuclear export signal within the high mobility group domain regulates the nucleocytoplasmic translocation of SOX9 during sexual determination. Proc. Nat1. Acad. Sci. 99: 11199-11204.

Hadjantonakis, A.K., Gertsenstein, M., Ikawa, M., Okabe, M., and Nagy, A. 1998. Generating green fluorescent mice by germline transmission of green fluorescent ES cells. Mech. Dev. 76: 79-90.

Haegel, H., Larue, L., Ohsugi, M., Fedorov, L., Herrenknecht, K., and Kemler, R. 1995. Lack of $\beta$-catenin affects mouse development at gastrulation. Development 121: 3529-3537.

Haffner-Krausz, R., Gorivodsky, M., Chen, Y., and Lonai, P. 1999. Expression of Fgfr2 in the early mouse embryo indicates its involvement in preimplantation development. Mech. Dev. 85: 167-172.

Hendrey, J., Lin, D., and Dziadek, M. 1995. Developmental analyses of the Hba (th-J) mouse mutation: Effects on mouse peri-implantation development and identification of two candidate genes. Dev. Biol. 172: 253-263.

Howe, C.C. and Solter, D. 1979. Cytoplasmic and nuclear protein synthesis in preimplantation mouse embryos. J. Embryol. Exp. Morphol. 52: 209-225.

Kamachi, Y., Sockanathan, S., Liu, Q., Breitman, M., LovellBadge, R., and Kondoh, H. 1995. Involvement of SOX proteins in lens-specific activation of crystallin genes. EMBO $J$. 14: 3510-3519.

Kamachi, Y., Uchikawa, M., and Kondoh, H. 2000. Pairing SOX off. Trends Genet. 16: 182-187.

Kishi, M., Mizuseki, K., Sasai, N., Yamazaki, H., Shiota, K., Nakanishi, S., and Sasai, Y. 2000. Requirement of Sox2-mediated signalling for differentiation of early Xenopus neuroectoderm. Development 127: 791-800. 
Larue, L., Ohsughi, M., Hirchenhain, J., and Kemler, R. 1994. E-cadherin null mutant embryos fail to form a trophectoderm epithelium. Proc. Natl. Acad. Sci. 91: 8263-8267.

Li, M., Pevny, L., Lovell-Badge, R., and Smith, A. 1998. Generation of purified neural precursors from embryonic stem cells by lineage selection. Curr. Biol. 8: 971-974.

Lu, C.C., Brennan, J., and Robertson, E.J. 2001. From fertilization to gastrulation: Axis formation in the mouse embryo. Curr. Opin. Genet. Dev. 11: 384-392.

Marotti, K.R., Berlin, D., and Strickland, S. 1982. The production of distinct forms of plasminogen activator by mouse embryonic cells. Dev. Biol. 90: 154-159.

Mortensen, R.M., Conner, D.A., Chao, S., Geisterfer-Lowrance, A.A.T., and Seidman, J.G. 1992. Production of homozygous mutant ES cells with a single targeting construct. Mol. Cell. Biol. 12: 2391-2395.

Nichols, J., Zevnik, B., Anastassiadis, K., Niwa, H., Klewe-Nebenius, D., Chambers, I., Schöler, H., and Smith, A. 1998. Formation of pluripotent stem cells in the mammalian embryo depends on the POU transcription factor Oct-4. Cell 95: 379-391.

Nishiguchi, S., Wood, H., Kondoh, H., Lovell-Badge, R., and Episkopou, V. 1998. Sox1 directly regulates the $\gamma$-crystallin genes and is essential for lens development in mice. Genes \& Dev. 12: 776-781.

Nishimoto, M., Fukushima, A., Okuda, A., and Muramatsu, M. 1999. The gene for the embryonic stem cell coactivator UTF1 carries a regulatory element which selectively interacts with a complex composed of Oct-3/4 and Sox-2. Mol. Cell. Biol. 19: 5453-5465.

Niswander, L. and Martin, G.R. 1992. Fgf-4 expression during gastrulation, myogenesis, limb and tooth development in the mouse. Development 114: 755-768.

Niwa, H., Miyazaki, J., and Smith, A.G. 2000. Quantitative expression of Oct-3/4 defines differentiation, dedifferentiation or self-renewal of ES cells. Nat. Genet. 24: 1-5.

Orr-Urtreger, A., Givol, D., Yayon, A., Yarden, Y., and Lonai, P. 1991. Developmental expression of two murine fibroblast growth factor receptors, flg and bek. Development 113: 1419-1434.

Overton, P.M., Meadows, L.A., Urban, J., and Russell, S. 2002. Evidence for differential and redundant function of the Sox genes Dichaete and SoxN during CNS development in Drosophila. Development 129: 4219-4228.

Palmieri, S.L., Peter, W., Hess, H., and Schöler, H.R. 1994. Oct-4 transcription factor is differentially expressed in the mouse embryo during the establishment of the first two extraembryonic cell lineages involved in implantation. Dev. Biol. 166: 259-267.

Pesce, M. and Schöler, H.R. 2000. Oct-4: Control of totipotency and germline determination. Mol. Reprod. Dev. 55: 452-457.

Poirier, F., Chan, C.-T.J., Timmons, P.M., Robertson, E.J., Evans, M.J., and Rigby, P.W.J. 1991. The murine $H 19$ gene is activated during embryonic stem cell differentiation in vitro and at the time of implantation in the developing embryo. Development 113: 1105-1114.

Rappolee, D.A. 1999. It's not just baby's babble/babel: Recent progress in understanding the language of early mammalian development: A minireview. Mol. Reprod. Dev. 52: 234-240.

Rappolee, D.A., Basilico, C., Patel, Y., and Werb, Z. 1994. Expression and function of FGF-4 in peri-implantation development in mouse embryos. Development 120: 2259-2269.

Rehberg, S., Lischka, P., Glaser, G., Stamminger, T., Wegner, M., and Rosorius, O. 2002. Sox10 is an active nucleocytoplasmic shuttle protein and shuttling is crucial for Sox10mediated transactivation. Mol. Cell. Biol. 22: 5826-5834.
Rossant, J. and Cross, J.C. 2001. Placental development: Lessons from mouse mutants. Nat. Rev. Genet. 2: 538-548.

Sanes, J.R., Rubenstein, J.L.R., and Nicolas, J.F. 1986. Use of a recombinant retrovirus to study post-implantation cell lineage in mouse embryos. EMBO J. 5: 3133-3142.

Shen-Li, H., O'Hagan, R.C., Hou Jr., H., Horner II, J.W., Lee, H.-W., and DePinho, R.A. 2000. Essential role for Max in early embryonic growth and development. Genes \& Dev. 14: $17-22$.

Solter, D. and Knowles, B.B. 1975. Immunosurgery of mouse blastocyst. Proc. Nat1. Acad. Sci. 72: 5099-5102.

Tam, P.P.L. and Behringer, R.R. 1997. Mouse gastrulation: The formation of a mammalian body plan. Mech. Dev. 68: 3-25.

Tanaka, S., Kunath, T., Hadjantonakis, A.-K., Nagy, A., and Rossant, J. 1998. Promotion of trophoblast stem cell proliferation by FGF4. Science 282: 2072-2075.

Tomioka, M., Nishimoto, M., Miyagi, S., Katayanagi, T., Fukui, N., Niwa, H., Muramatsu, M., and Okuda, A. 2002. Identification of Sox-2 regulatory region which is under the control of Oct-3/4-Sox-2 complex. Nucleic Acids Res. 30:32023213.

van Deursen, J., Boer, J., Kasper, L., and Grosveld, G. 1996. G2 arrest and impaired nucleocytoplasmic transport in mouse embryos lacking the proto-oncogene CAN/Nup214. EMBO J. 15: 5574-5583.

Varlet, I., Collignon, J., and Robertson, E.J. 1997. Nodal expression in the primitive endoderm is required for specification of the anterior axis during mouse gastrulation. Development 124: $1033-1044$

Wilder, P.J., Kelly, D., Brigman, K., Petersen, C.L., Nowling, T., Gao, Q.-S., McComb, R.D., Capecchi, M.R., and Rizzino, A. 1997. Inactivation of the FGF-4 gene in embryonic stem cells alters the growth and/or the survival of their early differentiated progeny. Dev. Biol. 192: 614-629.

Wilkinson, D.G. 1998. In situ hybridization: A practical approach. Oxford University Press, Oxford.

Wood, H. and Episkopou, V. 1999. Comparative expression of the mouse Sox1, Sox2 and Sox3 genes from pre-gastrulation to early somite stages. Mech. Dev. 86: 197-201.

Zappone, M.V., Galli, R., Catena, R., Meani, N., De Biasi, S., Mattei, E., Tiveron, C., Vescovi, A.L., Lovell-Badge, R., Ottolenghi, S., et al. 2000. Sox2 regulatory sequences direct expression of a $\beta$-geo transgene to telencephalic neural stem cells and precursors of the mouse embryo, revealing regionalization of gene expression in CNS stem cells. Development 127: 2367-2382. 


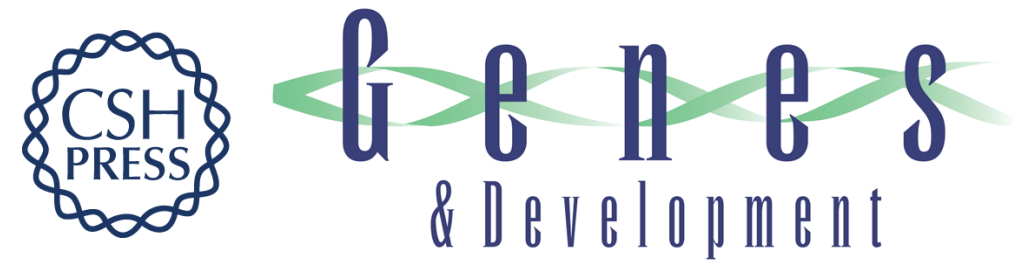

\section{Multipotent cell lineages in early mouse development depend on SOX2 function}

Ariel A. Avilion, Silvia K. Nicolis, Larysa H. Pevny, et al.

Genes Dev. 2003, 17:

Access the most recent version at doi:10.1101/gad.224503

Supplemental http://genesdev.cshlp.org/content/suppl/2003/01/06/17.1.126.DC1
Material

References This article cites 52 articles, 25 of which can be accessed free at: http://genesdev.cshlp.org/content/17/1/126.full.html\#ref-list-1

License

Email Alerting Receive free email alerts when new articles cite this article - sign up in the box at the top Service right corner of the article or click here.

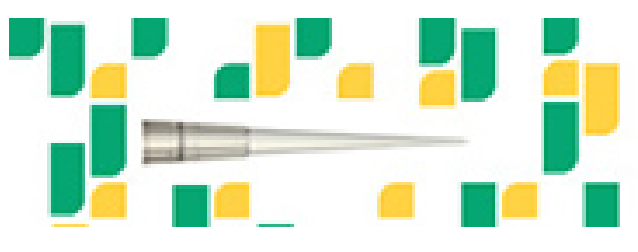

Focused on your science. 